\title{
A Critical Review of the Use of Wenger's Community of Practice (CoP) Theoretical Framework in Online and Blended Learning Research, 2000-2014
}

\author{
Sedef Uzuner Smith \\ University of Houston Downtown \\ Suzanne Hayes and Peter Shea \\ State University of New York, Albany
}

\begin{abstract}
After presenting a brief overview of the key elements that underpin Etienne Wenger's communities of practice $(\mathrm{CoP})$ theoretical framework, one of the most widely cited and influential conceptions of social learning, this paper reviews extant empirical work grounded in this framework to investigate online/blended learning in higher education and in professional development. The review is based on integrative research approaches, using quantitative and qualitative analysis, and includes CoP oriented research articles published between 2000 and 2014. Findings are presented under three questions: Which research studies within the online/blended learning literature made central use of the CoP framework? Among those studies identified, which ones established strong linkages between the CoP framework and their findings? Within this last group of identified studies, what do the patterns in their use of the CoP framework suggest as opportunities for future research in online teaching and learning?
\end{abstract}

Keywords: community of practice; Wenger; online and blended learning.

Smith, S. U., Hayes, S., \& Shea, P (2017). A critical review of the use of Wenger's Community of Practice (CoP) theoretical framework in online and blended learning research, 2000-

2014, Online Learning 21(1), 209-237. doi: 10.24059/olj.v21i1.963

\section{Introduction}

A great deal of empirical research investigating the use of online and blended approaches in higher education and professional development has drawn primarily on social constructivist theories of learning (Vygotsky, 1978). In many instances, this research was directly inspired by Lave and Wenger's (1991) and Wenger's (1998) theoretical claims, and in others it was motivated by the assumptions put forth by other influential social learning theorists. In this review, we look at published research studies where Wenger's communities of practice (CoP) theoretical framework provided a conceptual direction for the investigation of online and blended 
learning environments in higher education and in professional development. Our purpose is to examine critically the ways in which these studies used the CoP framework to research online/blended learning.

The impetus for this review came from our interest in examining the theory-research links in published studies of online/blended learning. Most major research methods textbooks and articles remind us that theory influences the types of questions (or hypotheses) researchers generate, and consequently it influences the answers obtained from those questions. The following quote from Kilbourn (2006, p. 545) attests to this view:

A fundamental assumption for any academic research is that the phenomena (data) that we wish to understand are filtered through a point of view (a theoretical perspective) that is to say, it is assumed that there is no such thing as a value-free or unbiased or correct interpretation of an event. Interpretations are always filtered through one or more lenses or theoretical perspectives that we have for "seeing"; reality is not something that we find under a rock.

There is also the contrasting view that theory is not always needed in research. Yet, what appears to be the general consensus on this point is the idea that "Research that is not theoretically informed, not grounded in the existing body of knowledge, or of the 'shotgun' variety that fails to raise and investigate conceptually grounded questions, is likely to generate findings of a narrow and ungeneralizable value" (Yiannakis, 1992, p. 8). It is this idea that initially gave rise to this review, and we determined our purpose to be that of critically examining how the CoP framework is used in published research studies on online/blended learning in higher education and professional development.

Before embarking on this task, we searched for any existing publications that might have already attempted what we sought to do. Our search yielded no such publication, and we found only one article (Consalvo, Schallert, \& Elias, 2015) that came closest to the focus of our review. This article critically examined the use of Lave and Wenger's (1991) construct of legitimate peripheral participation in literacy research. Although its focus and content are quite different from the review we present here, the Consalvo et al. (2015) article provided insights that helped us think through ways to conduct this review.

In conducting this review, we were guided by two goals. One was to critique the ways in which the $\mathrm{CoP}$ framework has been used in studies focusing on online/blended learning environments in higher education and professional development and to identify new possibilities for future research. Another was to aid current and future researchers in examining their own application of the CoP framework in detail.

Having described our purpose, we will now provide a brief summary of Wenger's CoP framework. For those readers seeking a detailed presentation of Wenger's ideas, we provide references to Wenger's own writings rather than secondary sources. Lastly, it is important to note that we did not intend to offer a critical analysis of Wenger's CoP framework. Rather, our goal is to provide a critical analysis of how this framework has been used in published research on online/blended learning. For those readers interested in a critical analysis of Wenger's ideas, we 
recommend the collection of essays in Hughes, Jewson, and Unwin (2007) as a good starting point.

\section{Summary of the CoP Framework}

When speaking of Wenger's notion of CoP, it is important to note that it has continued to grow in complexity and focus. The initial concept of CoP originated in Wenger's partnership with Jean Lave in their 1991 publication, “Situated learning: Legitimate peripheral publication." In this work, Lave and Wenger used an anthropological perspective to argue that learning is not just receiving or absorbing information. Rather, in their view, learning is "increasing participation in communities of practice” (Lave \& Wenger, 1991, p. 49). In his groundbreaking 1998 book, “Communities of practice: Learning, meaning, and identity,” focusing on workplace learning, Wenger expanded upon this idea of CoP, articulating how social resources shape people's learning trajectories and their professional identity. Following this publication, Wenger developed the concept of CoP further by presenting it as an approach to knowing and learning that is applicable to various contexts, including business, organizational design, government, education, and civic life. Undoubtedly, Wenger's notion of CoP is one of the most widely cited and influential conceptions of social learning to date.

More recently, Wenger, Trayner, and de Laat (2011) defined CoP as a "learning partnership among people who find it useful to learn from and with each other about a particular domain. They use each other's experience of practice as a learning resource” (p. 9). Taking this definition as our starting point, below we briefly explore the important concepts that underpin the principles of CoP.

\section{The Domain}

For Wenger (2004), the domain of a CoP constitutes "the area of knowledge that brings the community together, gives it its identity, and defines the key issues that members need to address" (para. 13). The domain, therefore, is what gives a group its identity and distinguishes it from a club of friends or a network of connections between people.

\section{The Community}

For Wenger (2004), the community constitutes "the group of people for whom the domain is relevant, the quality of the relationships among members, and the definition of the boundary between the inside and the outside" (para. 14). For a group of people to constitute a $\mathrm{CoP}$, its members must come together around ideas or topics of interest (the domain) and interact with each other to learn together.

\section{The Practice}

Wenger (2004) defines practice as "the body of knowledge, methods, tools, stories, cases, documents, which members share and develop together" to address recurring problems in their specific contexts (para. 15). To our knowledge, the most recent attempt to define this construct from a Wengerian perspective comes from Consalvo et al. (2015). These authors defined practice as "a way of acting in the world" and as "a field of endeavor and expertise" (p. 3). Combined, these definitions suggest that practice implies knowledge of and engagement with a domain. 


\section{Participation and Reification}

Wenger (1998) contended that individuals' engagement in a CoP always entails a process of negotiation of meaning which takes place in the convergence of two processes: participation and reification. Participation involves acting and interacting, and reification involves producing artifacts (such as tools, words, symbols, rules, documents, concepts, theories, and so on) around which the negotiation of meaning is organized. Participation and reification are complementary processes in that each has the capacity to make up for the limitations of the other. For instance, when reading about an idea does not make it clear to an individual, peers who have a better grasp of it may become a source for the individual's understanding through conversation, a form of participation. In the same way, giving shape to an idea through writing (a form of reification) may enhance one's meaning making in ways that discussing it with other people could not. Wenger, White, and Smith (2009) noted that learning in a CoP "requires both participation and reification to be present and in interplay" (p. 57).

\section{Joint Enterprise, Mutual Engagement, and Shared Repertoire}

Wenger (2010) emphasized that over time, through participation and reification, participants of a CoP develop and negotiate "a set of criteria and expectations by which they recognize membership" (p. 180). These criteria include:

- joint enterprise - a collective understanding of what the community is about, its purpose

- mutual engagement - interacting and establishing norms, expectations, and relationships; and

- shared repertoire - using the communal resources, such as language, artifacts, tools, concepts, methods, standards.

Wenger (1998, p. 137) posited that it is through joint enterprise, mutual engagement, and shared repertoire that a community establishes guidelines as to "what it is to be a competent participant, an outsider, or somewhere in between" and further adds that establishing such guidelines is crucial for learning to take place in a CoP.

\section{Engagement, Imagination, and Alignment}

According to Wenger, as people participate in a CoP, they express their belonging through three modes of identification:

- engagement - doing things together, talking, producing artifacts;

- imagination - reflecting, constructing an image of the practice and its members and seeing self as one of them;

- alignment - following directions, aligning self with expectations/standards, coordinating actions towards a common goal.

Wenger posited that these three modes of identification are not mutually exclusive and their presence is crucial to the transformation of a $\mathrm{CoP}$ into a site of learning. He noted, "The creation of learning communities [...] depends on dynamic combination of engagement, imagination, and alignment [...]” (Wenger, 1998, p. 228). 


\section{Boundaries}

People often belong to more than one CoP with each having boundaries that separate them from one another. In Wenger's view, boundaries connote difference: "They arise from different enterprises; different ways of engaging with one another; different histories, repertoires, ways of communicating, and capabilities” (Wenger, 2000, p. 125). In other words, being members of multiple CoPs means crossing boundaries.

\section{Brokering}

Crossing boundaries between different communities provides opportunities for brokering, a concept Wenger (1998) defined as the process of "transfer[ring] some element of one practice into another" (p. 109). He further added that good brokers are those that cause learning as they engage in import-export.

\section{Legitimate Peripheral Participation}

When individuals cross boundaries as outsiders or newcomers, they are offered possibilities for participation called peripheries. A newcomer's participation in a CoP often starts on the periphery - "a region that is neither fully inside nor fully outside” (Wenger, 1998, p. 117) and leads towards the center through growing involvement. This process of moving from the periphery to center is characterized by the concept of legitimate peripheral participation - a concept that was first developed by Lave and Wenger (1991). In Wenger's writings, the notion of legitimate peripheral participation is mentioned but it does not take center stage. Rather, it serves as important background condition under which newcomers become included in a CoP. Wenger's contribution to the development of this notion lies in his articulation of the special measures (e.g., observation, special assistance, close supervision, etc.) that may be taken to open up a practice to newcomers. He also noted, "No matter how the peripherality of initial participation is achieved, it must engage newcomers and provide a sense of how the community operates” (Wenger, 1998, p. 100).

\section{Identity}

Identity construction as a result of participating in and learning from the practices of a community is another topic that is initially explored in Lave and Wenger (1991) and further elucidated in Wenger's (1998) later work. Wenger reminded us that as people participate in a $\mathrm{CoP}$, they acquire new knowledge and simultaneously their sense of who they are, their identities, change. As he stated:

Because learning transforms who we are and what we can do, it is an experience of identity. It is not just an accumulation of skills and information, but a process of becoming - to become a certain person or, conversely, to avoid becoming a certain person (Wenger, 1998, p. 215).

\section{Knowledge}

Participants in CoP generate knowledge as they interact with each other, share information, experience, insight and advice and help each other solve problems. Over time, this combination of action and discourse eventually represents communal approaches to understanding and solving problems, and the process of reification transforms these shared knowledge into the tools and artifacts that embody a CoP's regime of competence. The 
community's knowledge is dynamic, not static. It is also explicit and tacit, as well as social and individual (Wenger, McDermott \& Snyder, 2002).

\section{Learning Architectures}

In his discussion of learning as participation and becoming, Wenger (1998) introduced four dualities to capture the general elements for designing learning in CoPs. These dualities are: (1) participation and reification; (2) designed/emergent; (3) local/global; and identification/negotiability.

The first duality reminds us of the need to hold doing/talking (participation) and producing objects (reification) in the correct proportion to each other in social learning systems. The second duality expresses the need to include improvisation and innovation (emergent) into the prescriptions of practice (designed), such as policies and plans. The third duality highlights the need to involve "those who organize learning and those who realize it" in the design of learning (Wenger, 1998, p. 234). The fourth duality expresses the need to distribute power to shape both the community and the individual. Along with these dualities, Wenger emphasized that a robust design for learning should involve:

- interactive technologies, communication facilities, joint tasks, availability of help, and peripherality (indication of engagement);

- transparency, explanations, reflection, and pushing boundaries (indication of imagination); and

- common focus, direction, plans, standards, policies, and distribution of authority (indication of alignment).

\section{Value Creation}

Wenger's later writings (Wenger, Trayner, \& de Laat, 2011) presented the concept of value creation as a way to describe and assess the nature of social learning in a CoP and what, if any, value is created as a result of CoP members' activities and in their interactions with others in informal networks. The primary recipients of this value are participants of a CoP, but value may also accrue to other stakeholders, such as the organizations in which CoP operate and their sponsors who invest resources.

Wenger et al. (2011) defined five different cycles of value creation generated within CoP: immediate value; potential value, applied value; realized value; and reframed value. Immediate value includes learning that is put to use immediately to solve a problem. Potential value includes benefits related to the shared skills and knowledge that can be realized at some time in the future. Applied value results from the application of shared skills and knowledge to new contexts. Realized value includes CoP participant and stakeholder reflections on how the skills and knowledge gained as a result of their participation in a CoP made a difference in their ability to achieve important goals. Lastly, reframed value involves the identification and definition of new criteria for success. 


\section{Methodology}

\section{Analytic Framework for the Review}

This review takes the form of an integrative research review, a type of literature review that comes closest to fulfilling the methodological requirements of traditional research. As stated by Szmigiel and Lee (2014), an integrative review consists of "five stages comparable to those in empirical research: research question formulation, data collection, data evaluation, data analysis, and interpretation and reporting” (p. 37). The process we followed for this review mirrored these stages. We began by developing the overarching questions that provided the boundaries for the review. Next, we searched for and selected the studies relating to our inquiry. We treated each study as a data source and used both qualitative and quantitative approaches to achieve a systematic data analysis procedure.

In the next sections, we provide our guiding questions, search strategy, and analytical approach followed by our findings and interpretations.

\section{Guiding Questions}

The overarching questions that guided this review were:

1. Which research studies within the online/blended learning literature made central use of the CoP framework?

2. Among those studies identified, which ones established strong linkages between the CoP framework and their findings?

3. Within the final group of studies identified, what do the patterns in their use of the CoP framework suggest as opportunities for future research in online teaching and learning?

\section{Search Strategy}

To identify the studies to be included in this review, we conducted a comprehensive search using six aggregator research database services: EBSCO Academic Search Premier, Gale One Search, ProQuest, EdIT (Education and Information Technology), Science Direct, and Sage. We used the following three topics to guide our search: 1) community of practice, 2) Wenger, and 3) online and blended learning. We also developed synonyms and phrases for each topic including their singular, plural and abbreviated forms, and then combined them using the Boolean operator AND. (See Appendix A for complete list of search terms). A limitation of this search was that only studies in the above-mentioned databases were identified. To account for the possibility of exclusion of relevant articles outside of these databases, we searched Google Scholar and used citation chaining.

We targeted research articles from peer-reviewed journals during this search and excluded non-research articles, conference papers, dissertations, books, and book chapters. We also excluded articles published in languages other than English. While we set no specific time range for our inclusion criteria, the latest publications identified for the review were from 2014 given that we conducted our search during the summer of 2015.

Initially, our search yielded 82 research studies. The majority of these focused on online/blended courses or programs in higher education, and some focused on professional 
development that uses online/blended delivery. From this latter group, we selected only those papers that had a community focus and represented formal learning experiences bounded by time limits as well as predetermined, communal goals and outcomes. We excluded papers in which online/blended professional development environments represented "affinity spaces" (Gee, 2005) where participants come and go as they please to connect with each other, to share personal/vocational interests/passions, and to learn something connected to those interests/passions. Upon completion of this selection process, we ended up with 60 research articles. This became our sample.

\section{Analytical Approach}

To answer the first two questions guiding this review, we used content analysis and coded all 60 articles by using coding schemes that we developed for the purposes of this review. During the content analysis, we evaluated our coding decisions for inter-rater reliability using Holsti's (1969) coefficient of reliability.

To determine which articles made central use of the CoP framework (Guiding question 1), we first developed the 'Theoretical Foundation' coding scheme (Table 1) based on Bates \& Taylor's (2013) argument that, "the quality of theory application depends not so much on where (i.e., literature review, method, discussion) theory is used, but how thoroughly theory is applied to the study" (p. 63). Accordingly, if the CoP theory formed the conceptual framework for a study, either solely or jointly with other theories, we assigned that study " 1 ," and if the CoP theory was referenced or mentioned but did not provide the conceptual direction for the study, we assigned that study “ 0. "

Table 1

Theoretical foundation coding scheme

\begin{tabular}{lcl}
\hline \multicolumn{1}{c}{ Criteria } & Code & \multicolumn{1}{c}{ Description } \\
\hline $\begin{array}{l}\text { Extent of theoretical } \\
\text { foundation }\end{array}$ & 1 & $\begin{array}{l}\text { CoP theory formed the conceptual framework for the } \\
\text { study, either solely or jointly with other theories. }\end{array}$ \\
0 & $\begin{array}{l}\text { CoP theory is referenced or mentioned but did not } \\
\text { provide the conceptual direction for the study. }\end{array}$
\end{tabular}

Next, we developed the 'Theoretical Linkage' coding scheme (Table 2) to determine which studies established strong linkages between the $\mathrm{CoP}$ framework and their findings (Guiding question 2). We developed this scheme based on the argument that theory "serves as the structure and support for the rationale for the study, the problem statement, the purpose, the significance and the research questions," but most importantly, it provides a grounding base for methods and a conceptual anchor for analysis and findings (Grant \& Osanloo, 2012, p. 12). Against this backdrop, we assigned "2" to a study whose analysis/findings clearly connected to CoP theory; assigned " 1 " to a study whose analysis/findings somewhat or partially connected to $\mathrm{CoP}$ theory; and assigned "0" to a study whose analysis/findings were not connected to CoP theory. 
Table 2

Theoretical linkage coding scheme

\begin{tabular}{lcl}
\hline \multicolumn{1}{c}{ Criteria } & Code & \multicolumn{1}{c}{ Description } \\
\hline $\begin{array}{l}\text { Extent of connection between CoP } \\
\text { theory and analysis/findings }\end{array}$ & 2 & $\begin{array}{l}\text { Analysis/findings are clearly connected to CoP } \\
\text { theory } \\
\text { Analysis/findings are somewhat or partially } \\
\text { connected to CoP theory }\end{array}$ \\
& 1 & Analysis/findings are not connected to CoP theory \\
\hline
\end{tabular}

To address the third guiding question, we used the data analysis technique of the constant comparison method. This method involved rereading each of the studies identified as having strong/clear theoretical linkages and exploring patterns in their use of the CoP framework. While doing this, we constantly compared patterns that emerged from one study to those that emerged from another. As patterns became apparent, we noted that some were related. We sorted and reclassified them and arrived at six core patterns, which we reported in our findings.

\section{Findings}

Guiding question 1. The coding we conducted with our sample of 60 research articles, using guiding question 1, yielded 41 studies that made substantial use of Wenger's CoP framework, either solely or jointly with other theories. In the remaining 19 studies, the CoP framework was referenced or mentioned but did not provide the conceptual direction for the investigation. Initial inter-rater reliability for this analysis was .95 and was negotiated to 1.00.

As can be seen in figure 1, among those 41 studies, the first study on online/blended learning making central use of the CoP theoretical framework dated back to the year 2000 . Between 2000 and 2010, 26 papers of this nature were published, paralleling the overall growth in enrollments and scholarship in online/blended learning (Allen \& Seaman, 2013). In the subsequent four years, 15 additional papers were published, followed by a peak of seven papers in 2011. It appears that within the domain of online/blended learning, the number of publications using CoP theory has begun to decline. 


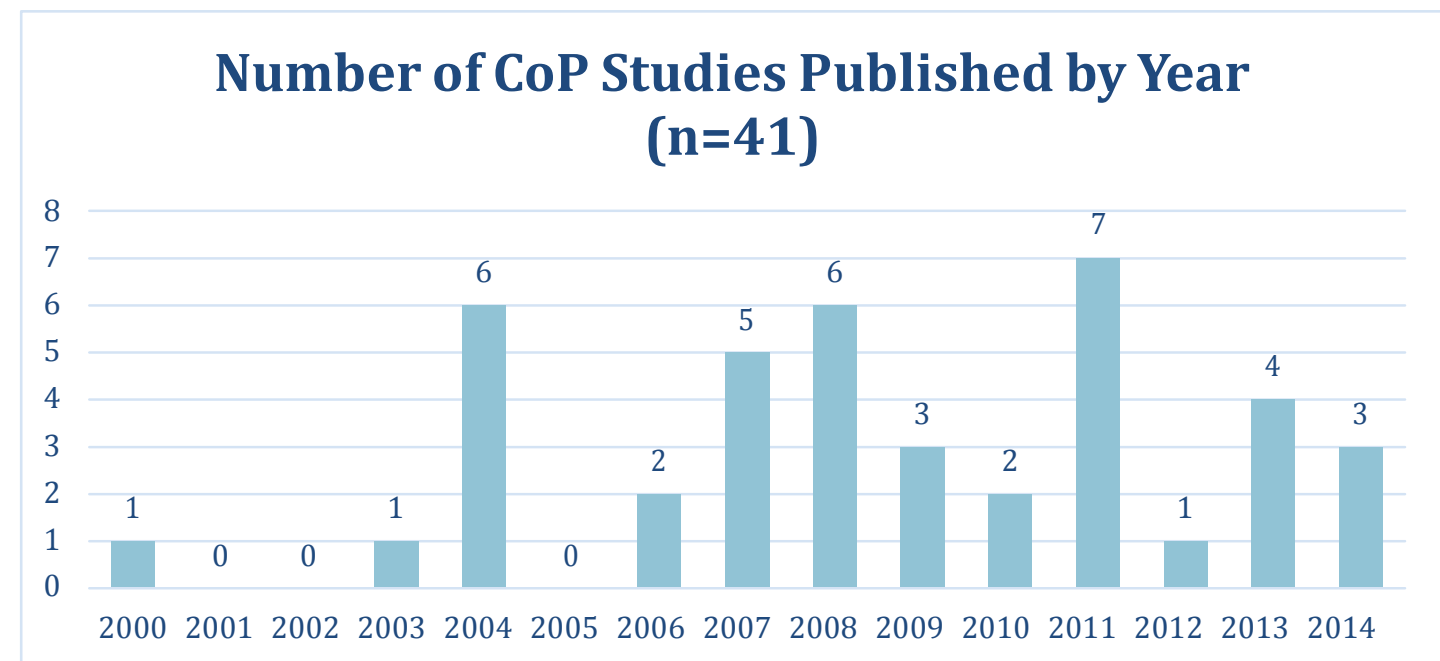

Figure 1. Publication year distribution of CoP-based research studies in online/blended learning

The majority of the studies we located were qualitative $(53.7 \%)$ and some used mixed methods (36.6\%). Only 9.8\% of all studies used a quantitative approach. Investigation of undergraduate and graduate level learning (78\%) far outnumbered investigation of professional development (22\%). Similarly, education courses were most often the site for CoP-based research (65.9\%), followed by those in health care and social services (12.2\%). The remainder were in other fields (17.1\%) or unidentified (4.9\%). Studies examining online courses accounted for just $36 \%$ versus $46.3 \%$ for blended courses. The remaining $17.7 \%$ used an online element but did not explicitly identify whether the course was fully online or blended. Lastly, $78 \%$ of the studies focused on the course level, with only $14.6 \%$ examining online/blended programs and 7.3\% addressing both areas.

Guiding question 2. In the second round of content analysis, we revisited the 41 studies identified for the guiding question 1 to determine if the authors had established strong linkages between the CoP framework and their analysis and findings. We found 17 studies that met this criterion (see Appendix B). In these studies, Wenger's CoP theory was central to the authors' data analysis efforts while also serving as the conceptual lens for interpretation of their findings. The 24 excluded studies failed to ground their analysis and/or results in Wenger's theory because of its absence or cursory use. For this analysis, the initial inter-rater reliability was .88 and was negotiated to 1.00 .

Guiding question 3. To address our third guiding question, which focused on identifying patterns in the use of the CoP framework among the final group of 17 studies, we used the data analysis technique of the constant comparison method. Below, we present the six primary patterns/themes that emerged from our analysis as potential avenues that future research may pursue.

Problematization versus theory verification. Overall, the majority of the studies generated from our search terms oriented toward theory verification - that is, they provided empirical confirmation of Wenger's theoretical assumptions. Theory verification was also 
evident in the final group of 17 studies that we identified for our guiding question 3 . In this group, we found six studies showing this trend: Evans, Yeung, Markoulakis, and Guilcher (2014), Gray (2004), Guldberg and Pilkington (2006), Moule (2006), Rogers (2000), and Brosnan and Burgess (2003). The aims of the first five studies coincided: Each sought to understand the extent or the nature of CoP formulation in the online learning environment. A common thread running through these studies was that they looked for evidence of the three essential characteristics of a CoP, i.e., mutual engagement, joint enterprise and shared repertoire, in their data. In the sixth study, Brosnan and Burgess (2003), the validity of Wenger's learning architecture concept was tested against what was seen to work well in an online course. All of these studies were theoretically sound; they verified how Wenger's theoretical assumptions correspond to the ways teaching and learning function in online and blended environments. However, the emphasis placed on theory verification led some of these studies to repeat the same general conclusions. It appeared that while the theory verification approach resulted in the design aspect of these studies being well grounded in CoP theory, it made their findings repetitive of the assumptions and findings that are already present in the literature.

One way of going beyond theory verification and avoiding the production of repetitive findings in research is to use the problematization approach proposed by Sandberg and Alvesson (2010). Sandberg and Alvesson defined this approach as "think[ing] differently, instead of what is already known" and "being able to formulate informed and novel questions" (p. 32). We argue that for CoP grounded online/blended learning research, the strategy of problematization implies disrupting the research emphasis on the verification of the best-known and over-researched Wengerian concepts (such as mutual engagement, joint enterprise and shared repertoire) and opening up new and previously unexplored areas for investigation.

A problematizing attitude, in the way described above, appeared evident in eight of the 17 studies included in our final analysis: Adams (2007); Clarke (2009); Cowan and Menchaca (2014); Goggins, Laffey, and Gallagher (2011); Guldberg and Mackness (2009); Mackey and Evans (2011); Nelson and Temples (2011); and Stacey, Smith, and Barty (2004). For example, drawing on Wenger's theory of identity formation in practice, Adams' (2007) study documented the struggles that ensued when art and design graduates transitioned from being an artist to becoming a teacher. The analysis revolved around analyzing the expressive and confessional nature of these new arts-teachers' online forum posts that revealed the complexities of their experiences. With this focus, the study was able to provide a refreshing perspective on the use of online forums as venues for personal exploration of identity and agency, particularly for newcomers to the teaching profession.

Another COP grounded study that offered a novel perspective on the contributions of online learning in teacher education is Clarke (2008). This study began by critiquing the standards model of teacher education, arguing that it is a flawed model that reduces teaching to a set of competencies to be mastered. Following this argument, it presented Wenger's CoP framework as a "more useful approach with which to analyze the complexity of new teachers' experiences" (p. 522) and illustrated the ways in which online components of a teacher education course can foster aspects of a CoP - namely the community, the domain of the community, community's shared practice, and community members' boundary crossings. Rather than 
verifying Wenger's CoP theory, this study developed from that theory a model of student teachers' online learning.

In sum, we contend that even though verification of the various elements of Wenger's CoP construct has provided many important insights into online/blended learning processes, there is need for researchers to develop a more problematizing attitude towards their investigations, as was done in Adams (2007) and Clarke (2008), than is currently the case.

Formation of a CoP versus formation of different types of community. More than half of the 17 studies included in our final analysis sought to determine whether the study participants actually attained a CoP (Clarke, 2009; Correia \& Davis, 2008; Ellaway, Dewhurst \& McLeod 2004; Goggins et al., 2001; Gray, 2004; Guldberg \& Mackness, 2009; Guldberg \& Pilkington, 2006; Rogers, 2000). Among these, two studies (Correia \& Davis, 2008; Guldberg \& Pilkington, 2006) stood out because, before the actual analysis, they identified a need for acknowledging how different dynamics lead to different types of communities. To illustrate this point, both studies drew on Henri and Pudelko's (2008) classification of four levels of communities: communities of interest; goal oriented communities; a learner's community; and communities of practice. By considering the strength of a group's social bonds (i.e., its level of cohesion) and the extent of its intentionality (i.e., the demonstrated purposefulness of its efforts) as a starting point, Henri and Pudelko differentiated these communities in the following ways: Communities of interest have the lowest cohesion of collective endeavor because they generate knowledge solely for individual use. Goal-oriented communities are driven by external forces to carry out a particular task within a specified timeframe. A learner's community relies upon the instructor for guidance and results in the generation of both individual and shared products. Finally, communities of practice are organized around professionals who perform similar activities and use their strong social bonds and high levels of intentionality to extend and improve their practices by building a base of shared knowledge or knowledge system(s). What is most notable about Henri and Pudelko's framework illustrating distinctions among communities is that it recognized the idea that learners do not necessarily form a CoP when they are part of a learning environment. We contend that this is an important point that any research seeking to understand the extent of $\mathrm{CoP}$ formation in online/blended learning environments should consider.

The dimension of time in CoP formation. Time is an important element in Wenger's CoP framework. The growth of novices into experts as they become enculturated into a CoP's regime of competence necessitates the passage of time. Time is also essential to Wenger's concept of identity. In a recent interview, Wenger noted that “... [I]dentity itself is a time/space concept" ... [in that] "you become a person out of a whole series of experiences over time" (Farnsworth, Kleanthous \& Wenger-Trayer, 2016, p. 11-12). In Wenger's own publications or in secondary sources that describe or interpret his theories, there is no clear-cut answer to the question of how much time is needed to arrive at a functioning $\mathrm{CoP}$, but a general contention is that "a shared repertoire cannot be rushed into existence" (Cousin \& Deepwell, 2005, p 61).

Within the final group of 17 studies, in all but one study (Ellaway et al., 2004) the temporal element of $\mathrm{CoP}$ formation was manifest as the duration of the online/blended courses or professional development opportunities that formed the research context. In these studies, the duration of time varied from as brief as 6 weeks (Moule, 2006) to 10 to 16 weeks (Correia \& 
Davis, 2008; Cross \& Pryor, 2008; Goggins et al., 2011; Mackey \& Evans, 2011; Nelson \& Temples, 2011; Stacy, Smith \& Barty, 2004). There were three exceptions that examined longer time frames. One was Clarke (2009), which reported on a 36-week long course that led to post graduate certificate in geography education. The others were Adams' (2007) yearlong study of a cohort of former art students making the transition to student teachers and Cowan and Menchaca's (2014) longitudinal analysis that examined an educational technology graduate program over a ten-year period. Similar variation was present when looking across the studies focusing on professional development. These studies ranged from 3 weeks (Rogers, 2000), 7 weeks (Gray, 2004; Guldberg \& Mackness, 2009), and 10 to 12-weeks (Brosnan \& Burgess, 2003; Evans et al., 2014), to one year (Guldberg \& Pilkington, 2006).

None of the aforementioned studies explored how time has contributed to the establishment of a functioning CoP. It appears that despite its importance in Wenger's CoP framework, time remains an unexplored variable in online/blended learning research grounded in this theory. We suggest that future research attempt to bring the issue of time to the forefront. One way to do this would be to identify how time contributes to, for example, the growth of novices into experts in online/blended course environments. Another way would be to examine how time impacts an online/blended course/program participant's development of an identity as someone who belongs to a CoP.

The need to unpack the epistemic and discursive practices typical of social practices.

The idea that learning happens through people's engagement in social practices lies at the heart of Wenger's CoP theory. Nevertheless, as important as social practices are to embodying and sustaining learning and knowledge within a CoP, an articulation of the epistemic and discursive practices typical of the communities that make up a social practice is missing from the literature. Arguing that Wenger's notion of social practices is largely undifferentiated, Amin and Roberts (2008) noted, "It is time that a more heterogeneous lexicon for different types of situated practice was developed” (p. 365). Amin and Roberts' critique emphasized that further clarity is warranted to identify the distinctive properties of learning and knowing that are situated within different types of social practices. We concur with this assessment and believe that more attention is needed to highlight the specialized ways of knowing, thinking, and doing that people need to internalize in order to participate in a particular social practice.

Looking across the final group of 17 studies, we found that only two studies (Crossard \& Pryor, 2008; Evans et al., 2014) detailed participants’ epistemic engagement. In their exploration of the online components of a blended course where doctoral students began their trajectory from the periphery of educational research to more central roles, Crossouard and Pryor (2008) documented how the students engaged with the disciplinary norms to develop the ability to think and act like researchers. Similar illustrations were also present in the Evans et al. (2014) study, which focused on physical therapists' use of evidence-based approaches in their practice. Because these studies did not set out to explore how one goes about doing things in the practices that formed the context for their investigation, they did not provide a full account of the situated learning and knowing embedded within those practices. Nevertheless, they merit praise for acknowledging, and partially documenting, the epistemic structures that need to be orchestrated to facilitate individuals' entry into particular practices. We contend that this is an area that needs 
further consideration in future online/blended learning research grounded in Wenger's CoP framework.

As Larreamendy-Joerns and Leinhardt (2006) wrote, participation in a social practice entails understanding "not only its substantive structure (i.e., facts, concepts, theories), but also its syntax - that is, the questions that guide inquiry, the tools that allow inferences and interconnections, and the actions and principles (rules) that validate knowledge” (p. 590). Future research focusing on online/blended learning environments through the lens of CoP theory should consider the identification and articulation of these structures and syntax (i.e., the epistemic and discursive practices) that are valued in specific disciplines and professions. Doing so will provide the beginnings of an understanding of how to better focus learners' social interactions in online/blended learning environments to facilitate their professional socialization.

Using technology tools to support learning activities in CoP focused courses. When introducing technology into a CoP, Wenger, White, Smith and Rowe (2005) warned of the danger of "confusing the community with the technology" (p. 2). In other words, merely establishing an electronic site to host distributed members of an existing or aspiring $\mathrm{CoP}$ to engage with each other is no guarantee of its success. The same cautions and principles apply to online and blended learning environments. In these environments, web-based technologies such as asynchronous and/or synchronous discussions typically serve as a means of ensuring learner engagement with each other for the purposes of generating communal knowledge and resources that form their social practice. Nevertheless, just adding these interactive spaces to an online/blended learning environment does not guarantee that the resulting interactions support the kinds of meaning making necessary for the development of a CoP.

Within the final group of 17 studies, nearly all relied on asynchronous discussions to examine the ways in which the various components of Wenger's CoP framework play out in online/blended learning environments. Among these, three studies stood out (Clarke, 2009; Crossouard \& Pryor, 2008; Evans et al., 2014). These studies distinguished themselves by their clarity in explicating how those discussions were used to support participants' interaction-based meaning making for the development of community specific practices. Clarke (2009) discussed using online discussion forums for reflective practice as well as for formal and informal sharing of resources. In Crossouard and Pryor (2008), the discussion forum enjoyed use as a space where students could problematize and reflect upon the process of conducting research and engage in peer assessment. Evans et al. (2014) mentioned the use of discussion areas for a series of authentic evidence-based practice learning activities. These three studies provide readers with a clear idea of how technology was used for the purposes of generating communal knowledge and resources. In the remaining studies, however, such clarity was absent.

We contend that in online/blended learning studies that are grounded in Wenger's CoP framework, if asynchronous/synchronous discussions are used as data sources to examine how learning unfolds in these spaces, then the learning activities that are used in those discussions need to be made explicit. Future research should be sensitive to this issue and avoid the tendency to present asynchronous/synchronous discussions as data sources without further explication. 
On a related note, we also argue that the heavy reliance upon discussion areas as the most common site of exploration for CoP oriented research suggests that there is a need to focus on other collaboration tools to examine the uptake and enactment of social practices within a CoP. In our final sample of 17 studies that relied on web-based interactive technologies as their focus of analysis, we identified only one study (Goggins et al., 2011) that used a learning management system-based wiki rather than a discussion board. This study demonstrated how wikis offer a viable alternative space to support both participation and reification of shared and negotiated meaning in an online learning environment. We suggest future $\mathrm{CoP}$ oriented research in online/blended learning go beyond the analysis of discussions and consider the integration of alternative spaces for studying participation and reification in the generation of social practices and communal knowledge.

Communicating the practical implications of CoP theory with caution. Wenger's theoretical assumptions about CoP constitute a very rich and complex theory that is challenging to apprehend and apply. As such, it is not surprising that in the final group of 17 studies we only found three studies (Brosnan \& Burgess, 2003; Rogers, 2000; and Ellaway et al., 2004) that provided practical implications of this theory. The Brosnan and Burgess study provided contextualized accounts of how the key elements of Wenger's learning architecture notion can be employed to evaluate and guide the design and support of a Web-based continuing professional development course. Rogers' study offered guidelines as well as examples of how the principles of Wenger's mutual engagement, joint enterprise, and shared repertoire concepts can be applied in online learning environments to foster cohesive communities. Ellaway et al. (2004) differed from the Bronson and Burgess (2003) and Rogers (2000) studies in that it did not offer straightforward practical implications. Nevertheless, the authors contribute a post-hoc evaluation model for assessing the success and value of a virtual learning environment in supporting the general characteristics of CoP as articulated in Wenger's construct of learning architecture. The 60 -item survey presented in this study can be used by instructors, designers, and students in the context of a specific course. As Ellaway et al. (2004) put it, their survey offers "a perspective of how successfully the [virtual learning environment] is serving the communities of practice involved with the course in question, and [...] provide[s] pointers to areas in which it could be improved to the benefit of that community” (p. 142).

The fact that we were only able to identify three studies of this nature out of the final 17 speaks to the need for more researchers conducting CoP oriented research on online/blended learning to clearly articulate and demonstrate the practical aspects of their findings. However, we say this with caution. Often there is a tendency for researchers to accept a theory uncritically, and thus the implications they draw out from it can be too neat or too facile. There can be no denying that some applications of the CoP theoretical framework that we see in online/blended learning research are cursory. With this in mind, we argue that future CoP oriented research should go beyond simplistic or cursory applications of Wenger's theoretical ideas by exploring and engaging with this theory in its complexity.

\section{Discussion and Conclusions}

In this literature review, our analysis showed how research publications prior to 2015 have used Wenger's CoP framework to investigate online/blended learning in higher education 
and in professional development. It also described avenues that both current and future researchers employing this framework can pursue in their investigation of online/blended learning environments. Below we summarize our findings and provide overall conclusions and recommendations.

An important finding was that authors of 41 studies made explicit reference to Wenger's $\mathrm{CoP}$ framework, stating that this theory provided conceptual direction for their investigation. However, 24 of these studies' use of the CoP framework was questionable when judged against criteria we generated from the guidelines provided by Grant and Osanloo (2012) and Bates and Taylor (2013) on the use of theory in research. Another important finding was that the majority of the remaining 17 studies concentrated on the verification of the best-known elements of the $\mathrm{CoP}$ theory: joint enterprise, mutual engagement, and shared repertoire. Few studies went further than this focus. This review therefore argues that online/blended learning research employing the CoP theory should enter a new phase of development. There is a need for studies that not only take up different aspects of Wenger's CoP theory but also go beyond the traditional practice of theory verification to provide more complex and more nuanced understandings of online/blended learning environments.

We have identified certain areas in this review as being worthy of further consideration for future CoP-oriented online/blended learning research. These include:

- moving toward more sophisticated ways of gauging the progress of $\mathrm{CoP}$ formation, as seen in Henri and Pudelko's (2008) model;

- considering how the passage of time impacts the establishment of a CoP and/or the process of professional identity development within an online course/program;

- making visible the nature of epistemic engagement, the modes of thinking and acting that matter in certain social practices to help individuals learn how to participate meaningfully within those contexts;

- articulating in detail the functions and uses of the technological tools that most effectively support and mediate a community's social and intellectual engagement; and

- exercising caution when demonstrating how specific elements from the CoP theory can be applied to inform the design and execution of online/blended learning.

Overall, we hope that these findings will help current and future researchers to think more critically about their own use of the CoP framework when researching online/blended learning environments. We believe this theoretical framework continues to have potential for shedding light on how individuals learn within these social and situated contexts. Yet, at this point, it seems fair to argue that we have not fully exploited what this theory has to offer. We hope that this review will serve as a trigger for new lines of inquiry that take full advantage of this theory to expand our understandings of the process of online/blended learning in higher education and professional development. 


\section{References}

Papers with three asterisks were eliminated during the analysis conducted for RQ1, i.e., "theoretical foundations" coding.

Papers with two asterisks were eliminated during the analysis conducted for RQ2, i.e., the "theoretical linkage" coding

Papers with a single asterisk remained at the end of two rounds of coding. Their analysis/findings illustrated the strongest connections to Wenger's theory. These are analyzed in the review conducted for RQ3 and are detailed in Appendix B.

Allen, I. E., \& Seaman, J. (2013). Changing Course: Ten Years of Tracking Online Education in the United States. Needham MA: Babson College Research Group.

***Arnold, N., Ducate, L., Lomicka, L., \& Lord, G. (2005). Using Computer-mediated Communication to Establish Social and Supportive. CALICO Journal, 22(3), 537-566.

***Assaf, L. C. (2005). Exploring Identities in a Reading Specialization Program. Journal of Literacy Research, 37(2), 201-236. http://doi.org/10.1207/s15548430jlr3702_4

***Asoodar, M., Atai, M. R., Vaezi, S., \& Marandi, S. S. (2014). Examining effectiveness of communities of practice in online English for academic purposes (EAP) assessment in virtual classes. Computers \& Education, 70, 291-300. http://doi.org/10.1016/j.compedu.2013.08.016

*Adams, J. N. P. (2007). Artists becoming teachers: Expressions of identity transformation in a virtual forum goldsmiths research online artists becoming teachers: Expressions of identity transformation in a virtual forum. International Journal of Art \& Design Education, 23(6), 264-273.

**Amrein-Beardsley, A., Foulger, T. S., \& Toth, M. (2007). Examining the development of a hybrid degree program: Using student and instructor data to inform decision-making. Journal of Research on Technology in Education, 39(4), 331.

Amin, A. \& Roberts, J. (2008). Knowing in action: Beyond communities of practice. Research Policy, 37, 353-369.

**Annese, S., \& Traetta, M. (2009). Psychosocial dynamics of blended communities: participating and positioning in learning contexts. Open and Interdisciplinary Journal of Technology, Culture and Education, 4(2), 90-106. http://www.ckbg.org/qwerty/index.php/qwerty/article/viewArticle/59 
Bates, J. S., \& Taylor, A. C. (2013). Taking stock of theory in grandparent studies. In Mark A. Fine and Frank D. Fincham (Eds). Handbook of family theories (pp. 51-70). New York, NY: Taylor \& Francis.

***Bell-Robertson, C. (2014). “Staying On Our Feet” Novice Music Teachers' Sharing of Emotions and Experiences Within an Online Community. Journal of Research in Music Education, 61(4), 431-451. Retrieved from http://jrm.sagepub.com/content/61/4/431.short

***Baxter, J. (2012). Who am I and What Keeps Me Going? Profiling the Distance Learning Student in Higher Education. International Review of Research in Open and Distance Learning, 13 (4), 107-129.

**Baxter, J., \& Haycock, J. (2014). Roles and student identities in online large course forums: Implications for practice. The International Review of Research in Open and Distributed Learning, 15(1), 21-40. Retrieved from http://www.irrodl.org/index.php/irrodl/article/view/1593

**Beckett, G. H., Amaro- Jiménez, C., \& Beckett, K. S. (2010). Students’ use of asynchronous discussions for academic discourse socialization. Distance Education, 31(3), 315-335. doi: 10.1080/01587919.2010.513956

*Brosnan, K., \& Burgess, R. C. (2003). Web based continuing professional development - A learning architecture approach. Journal of Workplace Learning, 15(1), 24-33. doi: 10.1108/13665620310458794

**Cesareni, D., Martini, F., \& Mancini, I. (2011). Building a community among teachers, researchers and university students: A blended approach to training. International Journal of Computer-Supported Collaborative Learning, 6(4), 625-646. doi: 10.1007/s11412-011-9126-8

**Chang, C. K., Chen, G. D., \& Li, L. Y. (2008). Constructing a community of practice to improve coursework activity. Computers \& Education, 50(1), 235-247. doi: 10.1016/j.compedu.2006.05.003

*Clarke, L. (2009). The POD model: Using communities of practice theory to conceptualise student teachers' professional learning online. Computers \& Education, 52(3), 521-529. doi: 10.1016/j.compedu.2008.10.006

**Conrad, D. L. (2008). From community to community of practice: Exploring the connection of online learners to informal learning in the workplace. American Journal of Distance Education, 22(1), 3-23. doi: 0.1080/08923640701713414 
*Correia, A., \& Davis, N. (2008). Intersecting communities of practice in distance education: the program team and the online course community. Distance Education, 29(3), 289-306. doi: $10.1080 / 01587910802395813$

Consalvo, A. L., Schallert, D. L., \& Elias, E. M. (2015). An examination of the construct of legitimate peripheral participation as a theoretical framework in literacy research. Educational Research Review, 16, 1-18. doi:10.1016/j.edurev.2015.07.001

Cousin, G., \& Deepwell, F. (2005). Designs for network learning: A communities of practice perspective. Studies in Higher Education, 30(1), 57-66.

doi: 10.1080/0307507052000307795

**Cowan, J. (2012). Strategies for developing a community of practice: Nine years of lessons learned in a hybrid technology education master's program. TechTrends, 56(1), 12-18. doi: 10.1007/s11528-011-0549-x

*Cowan, J. E., \& Menchaca, M. P. (2014). Investigating value creation in a community of practice with social network analysis in a hybrid online graduate education program. Distance Education, 35(1), 43-74. doi: 10.1080/01587919.2014.893813

*Crossard, B. and Pyror, J. (2008). Becoming researchers: A sociocultural perspective on assessment, learning and the construction of identity in a professional doctorate. Pedagogy, Culture \& Society, 16(3), 221-237.

***Dahlberg, G. M. \& Bagga-Gupta. (2013). Communication in the virtual classroom in higher education: Language beyond the boundaries of time and space. Learning, Culture and Social Interaction 2, 127-142. http://doi.org/10.1016/j.lcsi.2013.04.003

***Dawson, K., Cavanaugh, C., \& Sessums, C. (2011). Designing a professional practice doctoral degree in Educational Technology: Signature pedagogies, implications and recommendations. International Journal of ..., 25(3), 1-15. Retrieved from http://www.ijede.ca/index.php/jde/article/view/767

***Delahunty, J., Verenikina, I., \& Jones, P. (2014). Socio-emotional connections: identity, belonging and learning in online interactions. A literature review. Technology, Pedagogy and Education, 23(2), 243-265.

**Egan, J. P. (2013). Learning community or community of practice: Preliminary findings of a transfer of learning study. Issues in Information Science and Information Technology, 10, 137-144.

*Ellaway, R., Dewhurst, D., \& McLeod, H. (2004). Evaluating a virtual learning environment in the context of its community of practice. Alt-J, 12(2), 125-145.

doi: 10.1080/0968776042000216192 
*Evans, C., Yeung, E., Markoulakis, R., \& Guilcher, S. (2014). An online community of practice to support evidence-based physiotherapy practice in manual therapy. The Journal of Continuing Education in the Health Professions, 34(4), 215-23. doi:10.1002/chp.21253

Farnsworth, V., Kleanthous, I., \& Wenger-Trayner, E. (2015). Communities of practice as a social theory of learning: A conversation with Etienne Wenger. British Journal of Educational Studies, p. 1-22. Advanced online publication. doi:10.1080/00071005.2015.1133799

Gee, J. P. (2005). Affinity spaces: From age of mythology to today's schools. In D. Barton, \& K. Tusting, Beyond communities of practice: Language power and social context (pp. 214232). New York: Cambridge University Press.

*Goggins, S. P., Laffey, J., \& Gallagher, M. (2011). Completely online group formation and development: Small groups as socio- technical systems. Information Technology \& People, 24(2), 104-133. doi: 10.1108/09593841111137322

Grant, C., \& Osanloo, A. (2014). Understanding, selecting, and integrating a theoretical framework in dissertation research: creating the blueprint for your "house." Administrative Issues Journal: Connecting Education, Practice, and Research, 14(2), 1226. doi: 10.1046/j.0266-4909.2003.00051.x

*Gray, B. (2004). Informal learning in an online community of practice. Journal of Distance Education, 19(1), 20-35. Retrieved from http://eric.ed.gov/?id=EJ807836

*Guldberg, K., \& Mackness, J. (2009). Foundations of communities of practice: Enablers and barriers to participation. Journal of Computer Assisted Learning, 25(6), 528-538. doi: 10.1111/j.1365-2729.2009.00327.x

*Guldberg, K., \& Pilkington, R. (2006). A community of practice approach to the development of non-traditional learners through networked learning. Journal of Computer Assisted Learning, 22(3), 159-171. doi: 10.1111/j.1365-2729.2006.00171.x

**Henderson, M. (2007). Sustaining online teacher professional development through community design. Campus-Wide Information Systems, 24(3), 162-173. doi: 10.1108/10650740710762202

Henri, F. \& Pudelko, (2003). Understanding and analyzing activity and learning in virtual communities. Journal of Computer Assisted Learning, 19, 474-487.

**Hodges, T. E., \& Cady, J. (2012). Blended-format professional development and the emergence of communities of practice. Mathematics Education Research Journal, 25(2), 299-316. doi: 10.1007/s13394-012-0065-0 
Holsti, O. (1969). Content analysis for social sciences and humanities. Reading, MA: AddisonWesley.

**Hough, B., Smithey, M., \& Evertson, C. (2004). Using computer-mediated communication to create virtual communities of practice for intern teachers. Journal of Technology and Teacher Education, 12(3), 361-386.

Hughes, J., Jewson, N., \& Unwin, L. (2007). Communities of practice: Critical perspectives. New York: Routledge.

**Kayler, M., \& Weller, K. (2007). Pedagogy, self-assessment, and online discussion groups. Journal of Educational Technology \& Society, 10(1), 136-147.

Kilbourn, B. (2006). The qualitative doctoral dissertation proposal. Teachers College Record, 108 (4), 529-576.

***Kellogg, S., Booth, S. \& Oliver, K. (2014). A Social Network Perspective on Peer Supported Learning in MOOCs for Educators. International Review of Research in Open and Distance Learning, 15(5), 263-289.

***Lee, K., \& Brett, C. (2015). Dialogic understanding of teachers' online transformative learning: A qualitative case study of teacher discussions in a graduate-level online course. Teaching and Teacher Education, 46, 72-83. http://doi.org/10.1016/j.tate.2014.11.001

***Lee, J., Carter-Wells, J., \& Glaeser, B. (2006). Facilitating the Development of a Learning Community in an Online Graduate Program. Quarterly Review of Distance Education, 7(949), 13-33. Retrieved from http://eric.ed.gov/?id=EJ875021

***Lou, Y. (2004). Learning to solve complex problems through between- group collaboration in project- based online courses. Distance Education, 25(1). Retrieved from http://www.tandfonline.com/doi/abs/10.1080/0158791042000212459

Larreamendy-Joerns, J., \& Leinhardt, G. (2006). Going the distance with online education. Review of Educational Research, 76(4), 567-605

Lave, J., \& Wenger, E. (1991). Situated learning: Legitimate peripheral participation. London: Cambridge University Press. doi:10.2307/2804509

**Lim, J. H., Dannels, S. A., \& Watkins, R. (2008). Qualitative investigation of doctoral students' learning experiences in online research methods courses. Quarterly Review of Distance Education, 9(3), 223-236.

**Lin, T., Hsu, Y., \& Cheng, Y. (2011). Emerging innovative teacher education from situated cognition in a web-based environment. Online Journal of Educational TechnologyTOJET, 10(2), 100-112. Retrieved from http://eric.ed.gov/?id=EJ932230 
*Mackey, J., \& Evans, T. (2011). Interconnecting networks of practice for professional learning. The International Review of Research in Open and Distributed Learning, 12(3), $1-18$.

***Mackness, J., Waite, M., Roberts, G. \& Lovegrove, E. (2013). Learning in a Small, TaskOriented, Connectivist MOOC: Pedagogical Issues and Implications for Higher Education, International Review of Research in Open and Distance Learning, 14(4), 140159.

**Marken, J. A., \& Dickinson, G. K. (2013). Perceptions of community of practice development in online graduate education. Journal of Education for Library and Information Science, 54(4), 299-307.

*Moule, P. (2006). E-learning for healthcare students: Developing the communities of practice framework. Journal of Advanced Nursing, 54(3), 370-80. doi: 10.1111/j.13652648.2006.03813.x

**Murchu, D. O., \& Sorensen, E. K. (2004). Online master communities of practice: Collaborative learning in an intercultural perspective. European Journal of Open and Distance Learning, 2004(1). Retrieved from http://www.eurodl.org/materials/contrib/2004/Identifying_COPs.pdf

*Nelson, G., \& Temples, A. L. (2011). Identity construction as nexus of multimembership: Attempts at reconciliation through an online intercultural communication course. Journal of Language, Identity \& Education, 10(2), 63-82. doi: 10.1080/15348458.2011.563636

***Obura, T., Brant, W. E., Miller, F., \& Parboosingh, I. J. (2011). Participating in a Community of Learners enhances resident perceptions of learning in an e-mentoring program: proof of concept. BMC Medical Education, 11(1), 3. http://doi.org/10.1186/1472-6920-11-3

***Oliveira, I., Tinoca, L., \& Pereira, a. (2011). Online group work patterns: How to promote a successful collaboration. Computers \& Education, 57(1), 1348-1357. http://doi.org/10.1016/j.compedu.2011.01.017

***Olofsson, A. D. (2007). Participation in an Educational Online Learning Community From Individuality to Community - Net-based Learning in Transition. Educational Technology \& Society, 10(4), 28-38.

***Owston, R., Wideman, H., Murphy, J., \& Lupshenyuk, D. (2008). Blended teacher professional development: A synthesis of three program evaluations. The Internet and Higher Education, 11(3-4), 201-210. http://doi.org/10.1016/j.iheduc.2008.07.003 
**Razak, A. N., Saeed, M., \& Ahmad, Z. (2013). Adopting social networking sites (SNSs) as interactive communities among English foreign language (EFL) learners in writing: Opportunities and challenges. English Language Teaching, 6(11), 187-199. doi: 10.5539/elt.v6n11p187

*Rogers, J. (2000). Communities of practice: A framework for fostering coherence in virtual learning communities. Educational Technology \& Society, 3(3), 384-392.

**Rohleder, P., Bozalek, V., Carolissen, R., Leibowitz, B., \& Swartz, L. (2007). Students’ evaluations of the use of e-learning in a collaborative project between two South African universities. Higher Education, 56(1), 95-107. doi: 10.1007/s10734-007-9091-3

Sandberg, J., \& Alvesson, M. (2011). Ways of constructing research questions: Gap-spotting or problematization? Organization, 18(1), 23-44.

**Schrum, L., Burbank, M. D., \& Capps, R. (2007). Preparing future teachers for diverse schools in an online learning community: Perceptions and practice. The Internet and Higher Education, 10(3), 204-211. doi: 10.1016/j.iheduc.2007.06.002

*Stacey, E., Smith, P. J., \& Barty, K. (2004). Adult learners in the workplace: Online learning and communities of practice. Distance Education, 25(1), 107-123.

doi: $10.1080 / 0158791042000212486$

**Stewart, A. R., Harlow, D. B., \& DeBacco, K. (2011). Students' experience of synchronous learning in distributed environments. Distance Education, 32(3), 357-381. doi: 10.1080/01587919.2011.610289

Szmigiel, R., \& Lee, D. (2014). Avatars in E-and U-learning. In F. B. M. Neto (Ed.), Technology platform innovations and forthcoming trends in ubiquitous learning (pp. 35-58). Hershey, PA: Information Science Reference.

**Thang, S. M., Hall, C., Murugaiah, P., \& Azman, H. (2011). Creating and maintaining online communities of practice in Malaysian Smart Schools: challenging realities. Educational Action Research, 19(1), 87-105. doi: 10.1080/09650792.2011.547724

**Vaughan, N., \& Lawrence, K. (2013). Investigating the role of mobile devices in a blended pre-service teacher education program, Canadian Journal of Higher Education, 43(3), 56-78.

Vygotsky, L. S. (1978). Mind in society. Cambridge, MA: Harvard University Press.

***Walker, S., \& Creanor, L. (2005). Crossing complex boundaries: transnational online education in European trade unions. Journal of Computer Assisted Learning, 21(5), 343354. http://doi.org/10.1111/j.1365-2729.2005.00141.x 
Wenger E. (1998). Communities of practice: Learning, meaning and identity. New York, NY: Cambridge University Press.

Wenger, E. (2000). Communities of practice and social learning systems. Organization, 7(2), 225-246.

Wenger, E., McDermott, R., \& Snyder, W. (2002). Cultivating communities of practice: A guide to managing knowledge. Cambridge, MA: Harvard University Press.

Wenger, E. (2004). Knowledge management as a doughnut. Ivey Business Journal. Retrieved from: http://iveybusinessjournal.com/publication/knowledge-management-as-a-doughnut/

Wenger, E., White, N., Smith, J.D., Rowe, K. (2005). Technology for communities. In L. Langelier (Ed.), Working, learning and collaborating in a network: Guide to the implementation and leadership of intentional communities of practice (pp. 71-94). Quebec City: CEFIRO. doi:10.1109/ICSMC.2004.1399962

Wenger, E., White, N., \& Smith, J. D. (2009). Digital habitats: Stewarding technology for communities. Portland, OR: CPSquare.

Wenger, E. (2010). Communities of practice and social learning systems: The career of a concept. In C. Blackmore (Ed.), Social Learning Systems and Communities of Practice (pp. 179-198). London: Springer. doi:10.1007/978-1-84996-133-2

Wenger, E., Trayner, B., \& de Laat, M. (2011). Promoting and assessing value creation in communities and networks: A conceptual framework. Heerlen, The Netherlands: Ruud de Moor Centrum, Open University of the Netherlands.

***Wikeley, F., \& Muschamp, Y. (2004). Pedagogical implications of working with doctoral students at a distance. Distance Education, 25(1), 125-142. http://doi.org/10.1080/0158791042000212495

** Yukawa, J. (2010). Communities of practice for blended learning: Toward an integrated model for LIS education. Journal of Education for Library and Information ..., 51(2), 54. Retrieved from http://www.jstor.org/stable/20720485 


\section{Appendix A}

Search Topics Used to Conduct Literature Search

\begin{tabular}{|c|c|c|}
\hline Topic 1 & Topic 2 & Topic 3 \\
\hline $\begin{array}{ll}\text { - } & \text { community of } \\
\text { - } & \text { commuctice } \\
\text { practice } \\
\text { - } \\
\text { CoP }\end{array}$ & Wenger & $\begin{array}{ll}\text { - } & \text { online course(s) } \\
\text { - } & \text { blended course(s) } \\
\text { - } & \text { online learning } \\
\text { - } & \text { distance learning } \\
\text { - } & \text { e learning } \\
\text { - } & \text { elearning } \\
\text { - } & \text { learning management } \\
& \text { system } \\
\text { - } & \text { LMS } \\
\text { - } & \text { virtual learning } \\
\text { - } & \text { environment }\end{array}$ \\
\hline
\end{tabular}


Appendix B

Characteristics of Final Group of 17 CoP-grounded Research Studies

\begin{tabular}{|c|c|c|c|c|c|c|c|c|}
\hline & Authors & Discipline & $\begin{array}{l}\text { Research } \\
\text { Approach }\end{array}$ & $\begin{array}{c}\text { Online } \\
\text { (O) } \\
\text { Blended } \\
\text { (B) }\end{array}$ & $\begin{array}{l}\text { Course } \\
\text { (C) } \\
\text { Program } \\
\text { (P) }\end{array}$ & Focus & Context & $\begin{array}{c}\text { CoP } \\
\text { Concept(s) } \\
\text { Used }\end{array}$ \\
\hline 1 & Adams (2007) & $\begin{array}{l}\text { Education - } \\
\text { Arts }\end{array}$ & Qualitative & B & $\mathrm{C}$ & $\begin{array}{l}\text { Explores the experiences } \\
\text { of art and design } \\
\text { graduates as they } \\
\text { transition to becoming K- } \\
12 \text { art teachers using } \\
\text { Wenger's concepts of } \\
\text { identity and borders. }\end{array}$ & $\begin{array}{l}\text { An online forum used } \\
\text { in LMS to provide } \\
\text { communications and } \\
\text { support to student } \\
\text { teachers during their 9- } \\
\text { month school } \\
\text { placement. }\end{array}$ & $\begin{array}{l}\text { Identity, } \\
\text { boundaries }\end{array}$ \\
\hline 2 & $\begin{array}{l}\text { Brosnan \& } \\
\text { Burgess } \\
(2003)\end{array}$ & $\begin{array}{l}\text { Professional } \\
\text { Development - } \\
\text { Health and } \\
\text { human services }\end{array}$ & Qualitative & $\mathrm{O}$ & $\mathrm{C}$ & $\begin{array}{l}\text { Explores how Wenger's } \\
\text { notion of a learning } \\
\text { architecture can be } \\
\text { applied to evaluate and } \\
\text { guide the design of an } \\
\text { online professional } \\
\text { development course } \\
\end{array}$ & $\begin{array}{l}\text { A 12-week long online } \\
\text { professional } \\
\text { development course for } \\
\text { professionals from } \\
\text { health, education, } \\
\text { pharmacy and social } \\
\text { work backgrounds }\end{array}$ & $\begin{array}{l}\text { Learning } \\
\text { architecture }\end{array}$ \\
\hline 3 & Clarke (2009) & $\begin{array}{l}\text { Teacher } \\
\text { Education - } \\
\text { Geography }\end{array}$ & Qualitative & B & B & $\begin{array}{l}\text { Explores students' } \\
\text { perspectives of the online } \\
\text { components of a teacher } \\
\text { education course } \\
\text { designed using CoP } \\
\text { concepts. }\end{array}$ & $\begin{array}{l}\text { Cohorts of student } \\
\text { teachers use LMS- } \\
\text { designed environment } \\
\text { and forums to support } \\
\text { reflection, sharing of } \\
\text { classroom resources } \\
\text { and mutual support } \\
\text { during 36- week long } \\
\text { course. }\end{array}$ & $\begin{array}{l}\text { Domain, } \\
\text { community, } \\
\text { practice, and } \\
\text { brokering }\end{array}$ \\
\hline 4 & $\begin{array}{l}\text { Correia \& } \\
\text { Davis (2008) }\end{array}$ & $\begin{array}{l}\text { Teacher } \\
\text { Education }\end{array}$ & Qualitative & B & $\mathrm{C}, \mathrm{P}$ & $\begin{array}{l}\text { Examines the dynamics } \\
\text { of two complementary }\end{array}$ & $\begin{array}{l}\text { Program staff meet F2F } \\
\text { and online over several }\end{array}$ & $\begin{array}{l}\text { Community, } \\
\text { legitimate }\end{array}$ \\
\hline
\end{tabular}




\begin{tabular}{|c|c|c|c|c|c|c|c|c|}
\hline & & & & & & $\begin{array}{l}\text { and interacting } \\
\text { communities: One } \\
\text { involving program } \\
\text { instructors and } \\
\text { instructional developers; } \\
\text { the other involving } \\
\text { classroom and remote } \\
\text { students in a blended } \\
\text { program. }\end{array}$ & $\begin{array}{l}\text { years; Students in } \\
\text { semester long graduate } \\
\text { course, where some } \\
\text { students participate via } \\
\text { teleconferencing. }\end{array}$ & $\begin{array}{l}\text { peripheral } \\
\text { participation }\end{array}$ \\
\hline 5 & $\begin{array}{l}\text { Cowan \& } \\
\text { Menchaca } \\
(2014)\end{array}$ & $\begin{array}{l}\text { Education - } \\
\text { Technology }\end{array}$ & Mixed & B & $\mathrm{P}$ & $\begin{array}{l}\text { Examines Master's } \\
\text { program to assess value } \\
\text { created over its ten-year } \\
\text { history. }\end{array}$ & $\begin{array}{l}\text { An established hybrid } \\
\text { graduate program } \\
\text { designed and taught } \\
\text { using CoP principles. }\end{array}$ & $\begin{array}{l}\text { Value } \\
\text { creation } \\
\text { Framework }\end{array}$ \\
\hline 6 & $\begin{array}{l}\text { Crossard \& } \\
\text { Pryor (2008) }\end{array}$ & $\begin{array}{l}\text { Education - } \\
\text { Ed.D program }\end{array}$ & Qualitative & B & $\mathrm{C}$ & $\begin{array}{l}\text { Examines how tutor and } \\
\text { peer use of convergent } \\
\text { and divergent assessment } \\
\text { affected shift in identity. }\end{array}$ & $\begin{array}{l}\text { Part-time doctoral } \\
\text { students in a 16-week } \\
\text { blended educational } \\
\text { research methods } \\
\text { course. }\end{array}$ & $\begin{array}{l}\text { Legitimate } \\
\text { peripheral } \\
\text { participation, } \\
\text { identity }\end{array}$ \\
\hline 7 & $\begin{array}{l}\text { Ellaway, } \\
\text { Dewhurst, \& } \\
\text { McLeod } \\
(2004)\end{array}$ & $\begin{array}{l}\text { Heath Care - } \\
\text { Medicine }\end{array}$ & Quantitative & NA & $\mathrm{C}$ & $\begin{array}{l}\text { Describes the } \\
\text { development and } \\
\text { implementation of a post- } \\
\text { hoc evaluation } \\
\text { instrument based on } \\
\text { Wenger's learning } \\
\text { architecture to assess the } \\
\text { effectiveness of custom- } \\
\text { designed virtual learning } \\
\text { environment to support a } \\
\text { CoP. }\end{array}$ & $\begin{array}{l}\text { Administered to } \\
\text { students, faculty and } \\
\text { program staff in } \\
\text { undergraduate medical } \\
\text { school program }\end{array}$ & $\begin{array}{l}\text { Learning } \\
\text { architecture }\end{array}$ \\
\hline 8 & $\begin{array}{l}\text { Evans, Yeung, } \\
\text { Markoulakis, } \\
\text { \& Guilcher } \\
\text { (2014) }\end{array}$ & $\begin{array}{l}\text { Professional } \\
\text { Development } \\
\text { Health Care - } \\
\text { Physical } \\
\text { Therapy }\end{array}$ & Qualitative & $\mathrm{O}$ & $\mathrm{C}$ & $\begin{array}{l}\text { Examines how the LMS } \\
\text { and CoP concepts were } \\
\text { used to engage students } \\
\text { in authentic learning in } \\
\text { evidence-based research } \\
\text { practices course. }\end{array}$ & $\begin{array}{l}\text { Physical therapists in a } \\
\text { ten-week online } \\
\text { professional } \\
\text { development course }\end{array}$ & Community \\
\hline
\end{tabular}




\begin{tabular}{|c|c|c|c|c|c|c|c|c|}
\hline 9 & $\begin{array}{l}\text { Goggins, } \\
\text { Laffey, \& } \\
\text { Gallagher } \\
\text { (2011) }\end{array}$ & $\begin{array}{l}\text { Information } \\
\text { Systems - } \\
\text { Software } \\
\text { development }\end{array}$ & Mixed & $\mathrm{O}$ & $\mathrm{C}$ & $\begin{array}{l}\text { Explores how small } \\
\text { groups cooperate to } \\
\text { develop characteristics of } \\
\text { CoP in a tool-based } \\
\text { online course. }\end{array}$ & $\begin{array}{l}\text { Graduate students in a } \\
\text { semester long course in } \\
\text { Designing Performance } \\
\text { Support Systems. }\end{array}$ & Community \\
\hline 10 & Gray (2004) & $\begin{array}{l}\text { Professional } \\
\text { Development - } \\
\text { Human } \\
\text { Services }\end{array}$ & Qualitative & $\mathrm{O}$ & $\mathrm{C}$ & $\begin{array}{l}\text { Examines use of CoP } \\
\text { theory to shape informal } \\
\text { workplace learning in an } \\
\text { online course. }\end{array}$ & $\begin{array}{l}\text { A 7-week long } \\
\text { professional } \\
\text { development course for } \\
\text { local Adult Learning } \\
\text { Council coordinators. } \\
\end{array}$ & $\begin{array}{l}\text { Community, } \\
\text { identity }\end{array}$ \\
\hline 11 & $\begin{array}{l}\text { Guldberg \& } \\
\text { Mackness } \\
(2009)\end{array}$ & $\begin{array}{l}\text { Professional } \\
\text { Development - } \\
\text { Organization } \\
\text { Effectiveness }\end{array}$ & Mixed & $\mathrm{O}$ & $\mathrm{C}$ & $\begin{array}{l}\text { Explores barriers and } \\
\text { enablers to participation } \\
\text { in an international online } \\
\text { workshop designed as a } \\
\text { CoP. }\end{array}$ & $\begin{array}{l}\text { A 7-week long } \\
\text { professional } \\
\text { development course } \\
\text { sponsored for } \\
\text { academics and } \\
\text { managers hosted by } \\
\text { Wenger's consulting } \\
\text { firm. }\end{array}$ & $\begin{array}{l}\text { Community, } \\
\text { identity }\end{array}$ \\
\hline 12 & $\begin{array}{l}\text { Guldberg \& } \\
\text { Pilkington } \\
\text { (2006) }\end{array}$ & $\begin{array}{l}\text { Professional } \\
\text { Development - } \\
\text { Human } \\
\text { Services }\end{array}$ & Mixed & $\mathrm{O}$ & $\mathrm{C}$ & $\begin{array}{l}\text { Examines how } \\
\text { collaborative activities } \\
\text { based on Wenger's } \\
\text { concepts contributes to } \\
\text { the development of a } \\
\text { CoP }\end{array}$ & $\begin{array}{l}\text { Year-long professional } \\
\text { development course for } \\
\text { parents and caregivers } \\
\text { of people with Autism } \\
\text { spectrum disorder. }\end{array}$ & $\begin{array}{l}\text { Community, } \\
\text { identity, } \\
\text { boundaries }\end{array}$ \\
\hline 13 & $\begin{array}{l}\text { Mackey \& } \\
\text { Evans (2011) }\end{array}$ & $\begin{array}{l}\text { Teacher } \\
\text { education - } \\
\text { educational } \\
\text { technology }\end{array}$ & Mixed & NA & $\mathrm{C}$ & $\begin{array}{l}\text { Explores how } \\
\text { participants in formal } \\
\text { course-based learning } \\
\text { relate interconnecting } \\
\text { experiences between } \\
\text { practices, communities, } \\
\text { and opportunities. }\end{array}$ & $\begin{array}{l}\text { Wenger's theories used } \\
\text { to examine how } \\
\text { teachers in a graduate } \\
\text { course use learning and } \\
\text { resources from course- } \\
\text { based CoP to their } \\
\text { school-based CoPs. }\end{array}$ & $\begin{array}{l}\text { Identity; } \\
\text { multi- } \\
\text { membership } \\
\text { in multiple } \\
\text { communities; } \\
\text { boundaries; } \\
\text { brokers }\end{array}$ \\
\hline 14 & Moule (2006) & $\begin{array}{l}\text { Heath care - } \\
\text { Nursing, } \\
\text { radiology, } \\
\text { radiotherapy }\end{array}$ & Qualitative & $\mathrm{O}$ & $\mathrm{C}$ & $\begin{array}{l}\text { Examines how the } \\
\text { essential characteristics } \\
\text { of CoPs develop in } \\
\text { higher education online }\end{array}$ & $\begin{array}{l}\text { Assessed whether } \\
\text { students in their final } \\
\text { year of study in a 6- } \\
\text { week long online }\end{array}$ & $\begin{array}{l}\text { Mutual } \\
\text { engagement, } \\
\text { Joint } \\
\text { enterprise, }\end{array}$ \\
\hline
\end{tabular}




\begin{tabular}{|c|c|c|c|c|c|c|c|c|}
\hline & & & & & & learning environments. & $\begin{array}{l}\text { interprofessional } \\
\text { healthcare course were } \\
\text { able to develop a CoP }\end{array}$ & $\begin{array}{l}\text { Shared } \\
\text { repertoire }\end{array}$ \\
\hline 15 & $\begin{array}{l}\text { Nelson \& } \\
\text { Temples } \\
(2011)\end{array}$ & $\begin{array}{l}\text { Linguistics \& } \\
\text { Foreign } \\
\text { language } \\
\text { teaching }\end{array}$ & Qualitative & $\mathrm{O}$ & C, P & $\begin{array}{l}\text { Examined experiences of } \\
\text { two exchange students } \\
\text { using Wenger's CoP } \\
\text { concepts of identity and } \\
\text { reconciliation as students } \\
\text { participated in online } \\
\text { course, university and } \\
\text { host country. }\end{array}$ & $\begin{array}{l}\text { Online 15-week } \\
\text { intercultural } \\
\text { communications course } \\
\text { served as bridge to help } \\
\text { students negotiate their } \\
\text { identities at host } \\
\text { university and country. }\end{array}$ & $\begin{array}{l}\text { Identity, } \\
\text { reconciliation, } \\
\text { multi- } \\
\text { membership } \\
\text { multiple } \\
\text { communities }\end{array}$ \\
\hline 16 & Rogers (2000) & $\begin{array}{l}\text { Professional } \\
\text { Development - } \\
\text { TESOL }\end{array}$ & Qualitative & $\mathrm{O}$ & $\mathrm{C}$ & $\begin{array}{l}\text { Used Wenger's concepts } \\
\text { in exploratory study as } \\
\text { framework for analyzing } \\
\text { participant discourse to } \\
\text { determine whether } \\
\text { discourse was } \\
\text { characterized by three } \\
\text { essential elements of CoP }\end{array}$ & $\begin{array}{l}\text { 3-week long web-based } \\
\text { professional } \\
\text { development workshop } \\
\text { for ESOL teachers and } \\
\text { administrators }\end{array}$ & $\begin{array}{l}\text { Community; } \\
\text { mutual } \\
\text { engagement, } \\
\text { joint } \\
\text { enterprise } \\
\text { shared } \\
\text { repertoire }\end{array}$ \\
\hline 17 & $\begin{array}{l}\text { Stacey, Smith } \\
\text { \& Barty } \\
(2004)\end{array}$ & $\begin{array}{l}\text { Education - } \\
\text { Educational } \\
\text { Technology }\end{array}$ & Mixed & $\mathrm{O}$ & $\mathrm{C}$ & $\begin{array}{l}\text { Examined tensions that } \\
\text { result when students } \\
\text { move between course } \\
\text { learning community and } \\
\text { workplace CoPs. }\end{array}$ & $\begin{array}{l}22 \text { Masters students } \\
\text { enrolled in 13-week } \\
\text { course on the theory } \\
\text { and practice of e- } \\
\text { learning. }\end{array}$ & $\begin{array}{l}\text { Community, } \\
\text { reconciliation, } \\
\text { multi- } \\
\text { membership }\end{array}$ \\
\hline
\end{tabular}

